Many smaller failings-poor copy editing and outright errors-contribute to the impression of a poorly planned, hastily put together work. The New Sabin by no means supersedes Joseph Sabin's monumental Dictionary, and in its present form it fails to make a significant contribution of its own to the bibliographical control of Americana. -Doris Ann Sweet, Columbia University Libraries, New York City.

Carter, Mary Duncan; Bonk, Wallace John; and Magrill, Rose Mary. Building Library Collections. 4th ed. Metuchen, N.J.: Scarecrow, 1974. 415p.

This fourth edition of a library school "classic" has grown by some hundred pages yet remains, unsurprisingly, no more than a once-over-lightly of the complexities of acquisitions theory and practice. In an attempt to be inclusive it ranges from discussion of selection philosophies through description of national and trade bibliographies to a brief analysis of the uses of fanfold processing slips. As an introduction the text has already proven effective, although its usefulness is limited for experienced librarians.

The orientation is definitely toward public libraries, with an emphasis on the varying factors involved in book selection for different types and sizes of user communities. In an informally readable style the text restates commonsense principles and again illustrates that selection is more of an art than a science. Roughly the first half of the book is coverage of general theories while the second half is evenly split between description of acquisition aids and appendixes. The considerable portion of the text summarizing features of major bibliographic tools provides useful example entries to illustrate inclusiveness and format. Of course one difficulty with any book which tries to describe current bibliographic sources is that it is almost certain to be out of date by the time of publication. This edition has already missed the metamorphosis of Publishers' Weekly, the fifteenth edition of Ulrich's, and of course the recently announced separation of Library Journal and School Library Journal.

Discussion of the publishing trade and acquisitions practices is sketchy (e.g., no mention of NPAC), but throughout the book expanded bibliographies at chapter ends recommend a good range of additional material and have been brought well up to date. The approximate quarter of the volume devoted to appendixes offers a useful assortment of ALA Council statements on the freedom to read and a variety of quotations from book selection policies. Another interesting section is the text of the June 1973 Miller vs. California Supreme Court obscenity decision.

Occasional lapses in editing, generally of the typographical variety, are still evident in this new edition. Perhaps it was my misfortune to encounter the only blind cross reference in the index when I chose to look up USBE. However, even these minor slips are regrettable in a text which presumably will be read with close attention by prospective librarians.

In summary, the book is fine for its intended audience but of limited utility beyond library school classes.-Karen Horny, Assistant University Librarian for Technical Services, Northwestern University Library, Evanston, Illinois.

Schad, Jasper G., and Tanis, Norman E. Problems in Developing Academic Library Collections. New York: Bowker, 1974. 183p.

Collection development and acquisitions problems have often been relegated a minor role in library school curricula. The reasons for this vary, but the net result is the same-graduates with little practical, let alone theoretical, basis for action. In an attempt to counter this situation, the authors, both library directors, have created thirty case studies based on real situations, ranging from one to twenty pages in length. Superficially viewed, these studies might appear to be lacking in depth and subtlety, but a careful reading proves this not to be the case. Each situation is carefully constructed to present directly or by inference problems and dilemmas concerning a surprisingly broad range of topics.

Especially important for the student is the political and economic backdrop against which these problems are cast. Who really implements library policy? What is the proper balance between the academic administration, the library administration, the library staff, the faculty? Who controls 
the allocation of book funds? Additionally, intralibrary questions of power and responsibility are interwoven with classical problems relating to territorial imperatives, adversary relationships, tradition, and innovation.

This, then, is the background on which the concrete problems are displayed. Among the major themes under review are the consequences of approval plans, faculty and/or library responsibility for book selection, acquisitions policies, rare book/special collections versus ordinary needs, budget cuts and increases; faculty challenging the relevancy of purchases, and the question of such axioms as "building on strength." These, and issues such as the intellectual prerequisites and perspective of library staff and faculty in collection development, focus on topics germane to academic librarianship today. Perhaps the most important element in congealing these studies into a coherent whole is the dextrous interplay of issues and personalities. The ability to isolate problems and, additionally, to place the problems in a realistic matrix of human interaction demonstrates considerable sensitivity to the forces at work. This is a constructive and provocative book which, hopefully, will find its way into the hands of both students and practitioners.-W. Stuart Debenham, Jr., Assistant Director, Ohio College Library Center, Columbus.

\section{OTHER BOOKS OF INTEREST TO ACADEMIC LIBRARIANS}

Ackoff, Russell L., ed. Systems and Management Annual 1974. New York: Petrocelli Books, 1974. 620p. \$24.95. (746464). (ISBN 0-88405-280-X).

Armitage, Andrew D., and Tudor, Dean. Annual Index to Popular Music Record Reviews, 1973. Metuchen, N.J.: Scarecrow, 1974. 681p. (73-8909). (ISBN 08108-0774-2).

Bell, Inglis F., and Baird, Donald. The English Novel, 1578-1956; A Checklist of Twentieth-Century Criticisms. Hamden, Conn.: Shoe String Press, 1974. 168p. (74-8609). ISBN 0-208-01442-X).

Body, Alexander C. Annotated Bibliography of Bibliographies on Selected Government Publications and Supplementary
Guides to the Superintendent of Documents Classification System; 4th Supplement. Kalamazoo: Western Michigan University, 1974. 142p. (67-28593).

Bull, Storm. Index to Biographies of Contemporary Composers. v.2. Metuchen, N.J.: Scarecrow, 1974. 567p. \$18.50. (6411781). (ISBN 0-8108-0734-3).

Cambridge Research Institute. Omnibus Copyright Revision; Comparative Analysis of the Issues. Washington, D.C.: American Society for Information Science, 1973. (73-84952). (ISBN 0-87715103-2).

Clapp, Jane. Professional Ethics and Insignia. Metuchen, N.J.: Scarecrow, 1974. 863p. \$27.50. (74-10501). (ISBN 08108-0735-1).

Covo, Jacqueline. The Blinking Eye: Ralph Waldo Ellison and His American, French, German and Italian Critics, 1952-1972. Metuchen, N.J.: Scarecrow, 1974. 230p. $\$ 6.50$. (74-13042). (ISBN 0-8108-0736$\mathrm{X)}$.

Davis, Donald G. Comparative Historical Analysis of Three Associations of Professional Schools. (Occasional Papers, no. 115) Urbana, Ill.: Graduate School of Library Science, University of Illinois, 1974. 39p. \$1.00. (ISBN 0073-5310).

Directory of American Scholars. 6th ed. New York: Bowker, 1974. 4v. \$148.50. (57-9125). (ISBN 0-8352-0635-1).

Directory of Health Sciences Libraries in the United States, 1973. Chicago: American Medical Assn., 1974. 196p. \$15.00. (74-14292).

Farber, Evan I., and Walling, Ruth, eds. The Academic Library: Essays in Honor of Guy R. Lyle. Metuchen, N.J.: Scarecrow, 1974. 171p. \$6.00. (74-2098). (ISBN 0-8108-0712-2).

Fink, Gary M. Biographical Dictionary of American Labor Leaders. Westport, Conn.: Greenwood, 1974. 559p. \$19.95. (74-9322). (ISBN 0-8371-7643-3).

Fout, John C. German History and Civilization, 1806-1914; A Bibliography of Scholarly Periodical Literature. Metuchen, N.J.: Scarecrow, 1974. 362p. (7410803). (ISBN 0-8108-0742-4).

Fundaburk, Emma L. Art at Educational Institutions in the United States. Metuchen, N.J.: Scarecrow, 1974. 670p. (743187). (ISBN 0-8108-0715-7). 